\title{
NEUROPHYSIOLOGICAL ASSESSMENT OF COGNITIVE DYSFUNCTION IN PATIENTS WITH MULTIPLE SCLEROSIS
}

Svetlana Miletic Drakulic,

Clinic of neurology, Clinical Center Kragujevac, Kragujevac, Serbia

Faculty of Medical Sciences, University of Kragujevac, Kragujevac, Serbia

\author{
NEUROFIZIOLOŠKO MERENJE KOGNITIVNIH DISFUNKCIJA \\ KOD BOLESNIKA SA MULTIPLOM SKLEROZOM \\ Svetlana Miletić Drakulić \\ Klinika za neurologiju, Klinički centar Kragujevac, Srbija \\ Fakultet medicinskih nauka, Univerzitet u Kragujevcu, Kragujevac, Srbija
}

Received / Primljen: 28. 06. 2016.

Accepted / Prihvaćen: 14. 07. 2016.

\begin{abstract}
Cognitive impairment occurs in a high percentage in all forms of multiple sclerosis, regardless of physical disability. Slowing the speed of information processing is one of the most difficult and the most frequently mentioned, but impairment of memory, attention, executive functions are included also. Long latency event related potentials (ERP) are much more objective means of cognitive functioning evaluation. Different types of immunomodulatory therapies which are used for relapsing-remitting forms of multiple sclerosis may affect the results of ERP. ERP can evaluate subclinical changes and provide important information on the evolution of cognitive changes in patients with MS.
\end{abstract}

Keywords: multiple sclerosis, cognitive function, cognitive evoked potentials

\section{SAŽETAK}

Oštećenje kognitivnih funkcija se javlja u visokom procentu u svim formama multiple skleroze nezavisno od fizičke onesposobljenosti. Usporavanje brzine procesuiranja informacija je jedna od najtežih $i$ najčešće pominjanih, ali tu spadaju i oštećenje pamćenja, pažnje i egzekutivnih funkcija. Kognitivni potencijali kasnih latenci (ERP) su mnogo objektivnije sredstvo za evaluisanje kognitivnog funkcionisanja. Različite vrste imunomodultaornih terapija koje se koriste kod relapsno-remitetne forme multiple skleroze mogu imati uticaj na rezultate ERP. ERP nalazi mogu otkriti subkliničke promene $i$ obezbediti važne informacije o kognitivnim oštećenjima u bolesnika sa multiplom sklerozom.

Ključne reči: multipla skleroza, kognitivne funkcije, kognitivni evocirani potencijali

\section{ABBREVIATIONS \\ MS - Multiple Sclerosis \\ ERP - Event related potential}

\section{INTRODUCTION}

Cognitive impairment is a common feature in patients with multiple sclerosis, documented the high frequency up to $65 \%$ (1). Cognitive impairment occurs independently of physical disability and duration of the disease and occurs in all forms of MS (2). Slowing of the speed of information processing is one of the most difficult and the most frequently mentioned dysfunction, but there are damage of working memory, attention, executive function as well. Some patients early show neurobehavioral changes during the disease, while others never. The degree of cognitive deficit is highly variable.

Cognitive dysfunction can be evaluated by a battery of different neuropsychological tests, procedures that last about 3 to 5 hours and depend on the cooperation of patients. The main limitation in the application of these tests in patients with MS is a physical disability, reduced visual activity and motoric limit. On the other hand, it was shown that quick Mini Mental test (MMSE) is very insensitive for mild cognitive dysfunction. PASAT (Paced Auditory Serial Addition Test) proved to be a test which score is affected by education, training, anxiety and physical ability that is often impaired in MS (3). 
Long latency event related potentials (ERP) are much more objective means of cognitive functioning evaluation (4). Typical ERP waves elicited by the "oddball" paradigm with auditory and visual stimulation, in which occasional target stimuli have to be detected in a train of frequent irrelevant standard stimuli evokes a number of ERP components. In the performing of this test, the response to the rare tone is more complex, consisting P300 negative deflection. P300 component (P3) is known as an objective measure of individual cognitive functioning. P300 is a neurophysiological correlate of cognition and can be considered an internal memory model. It occurs $300 \mathrm{~ms}$ after stimulation and the maximum amplitude is recorded with the parietal scalp. This method of assessment of cognitive functioning in MS patients is very suitable because it is relatively independence from their visual and motor impairment, that are often in these patients.

Still the generator source of these waves is not reliably confirmed, but a lot of data suggest that the medial part of the temporal lobes and the temporal-parietal associative cortex can play a major role in the generation of these waves. It is assumed that the peak latency of this wave is the indicator of information processing speed since it is completely independent of motor activity and it is the process of making reaction choice. Prolonged latency of P300 represents an extension of time information processing while reducing the amplitude and abnormal topographic distribution reflects either weaker activation of the generator (frontal, parietal cortex, the thalamus and the temporal-medial cortex) or time dispersion of information processing. There is not enough data that the prolonged latency P300 in diseases is associated with general cognitive decline especially if it is characterized by slowing of the intellectual process.

Previous electrophysiological studies suggest that patients with MS have a significantly increased latency and decreased amplitude waves P300 with the auditory ERPcompared to healthy $(4,5)$. Whelan presented a significant difference in amplitude and latency between MS patients andthe healthy (6). The same author finds that were no significant differences between RRMS (relapsing-remitting multiple sclerosis) and SPMS (secondary progressive multiple sclerosis) patients on any ERP component. Longitudinal study presented that the decreased in amplitudes over 12-month period was greater in MS patients relative to controls and change in P3 amplitudes correlate with change in PASAT score in MSpatients over 12-month period (7). Although there are conflicting opinions that there is no difference in P3b latency and amplitude between MS patients and healthy (8). It is shown that latency of P300 poorly correlated with the duration of the disease (4). Nevertheless, recently published work indicates that cognitive capacity at MS patients is better expressed withlower amplitude and longer response time (9).

For now, the relationship between the lesions and neuropsychological cognitive function is not clearly defined in the MS. The application of MRI technique is the attempt to explain the mechanisms responsible for the development of cognitive deficits in patients with MS. Available data suggest that focal lesions in the white matter of the brain crucial areas play an important role in the development of cognitive deficit $(2,10)$. Irreversible tissue loss, brain atrophy, is associated with cognitive deficits. And other components of MS pathology such as diffuse damage, the phenomenon of the normal-appearing white matter (NAWM) and damage the gray matter (GM) play the role in determining the cognitive profile (10). It has been shown that delayed P300 latency correlated with the existence of extensive lesions of the white matter of the brain seen at magnetic resonance. This can lead to the assumption that white matter lesions may be responsible for cognitive deficits, abnormalities of ERP, which is explained by blocking functional fibers that connect different cortical regions. Some authors associate P300 latency extension with white matter lesions around the frontal horn and brain stem (5).

Study with functional magnetic resonance imaging (fMRI) indicate that performance of cognitive task in RRMS patients is associated with activation of higher cortical area in bilateral prefrontal and lower parietal cortex compared with control (11). Different patterns of cortical activations demonstrated an adaptive role in some stages of the disease.

Different types of, immunomodulatory therapies: Interferon beta and Natalizumab, which are applied in these patients may have an impact on the result of ERP (12). The authors give examples of the administration of high doses of corticosteroids, which are used in these patients relapses therapy may significantly reduce latency of P300 (13). It not only affects the level of motor and sensory functions but also at the high level of cognitive functioning. The same authors believe that the latency of P300 waves can be used to detect the changes caused by therapy and thus monitor the effect of treatment.

Dysfunction in speed of information processing is the prominent feature of cognitive impairment in MS and it is therefore important to identify cognitive deficits and often to control it. It is shown that training and motivation improve performance and significant impact on P300 amplitude (14).

By measuring the fluctuations in cognition may be useful as an additional measure for monitoring disease activity, monitoring therapy in MS. ERP can evaluate subclinical changes and provide important information on the evolution of cognitive changes in patients with MS.

\section{REFERENCES}

1. Hoffmann S, Tittgemeyer M, von Cramon DY.(2007) Cognitive impairment in multiple sclerosis. Curr Opin Neurol 2007; 20(3): 275-80.

2. Amato MP, Zipoli V, Portaccio E.(2006) Multiple sclerosis-related cognitive changes: a review of crosssectional and longitudinal studies. J Neurol Sci 2006; 245(1-2): 41-6. 
3. Barker-Collo SL.(2005) Within session practice effects on the PASAT and clients with multiple sclerosis. Arch Neuropsychol Clin. 2005; 20(2): 145- 52.

4. Ivica N, Titlic M, Pavelin S. (2013) P300 wave changes in patients with multiple sclerosis. Acta Med Inform. 2013; 21(3): 205-7.

5. Piras MR, Sognano I, Cani ED at all. Longitudinal study of cognitive dysfunction in multiple sclerosis: neuropsychological, neuroradiological and neurophysiological findings. J Neurol, Neurosurg, Psychiatry 2003;74:878-885.

6. Whelan R, Lonergan R, Kiiski H, Nolan H, Kinsella K, Bramham J, O’Brien M, Reilly RB, Hutchinson M, Tubridy N. A high-density ERP study reveals latency, amplitude, and topographical differences in multiple sclerosis patients versus controls. Clin Neurophysiol 2010;121(9):1420-6.

7. Kiiski H, Reilly RB, LonerganR at all.(2011) Change in PASAT correlates with in P3 ERP amplitude over a 12 -month period in multiple sclerosis patients. Journal of the Neurological Science 2011;305(1):42-52.

8. Sailer M, Heinze HJ, Tendolkar I, Decker U, KreyeO, v Rolbicki U, Münte TF (2001). Influence of cerebral lesion volume and lesion distribution on eventrelated brain potentials in multiple sclerosis. J Neurol 2001;248(12):1049-55.
9. Mathias Sundgren, Vadim V, Nikulin, Liselotte Maurex, ÅkeWahlin, Fredrik Piehl, Tom Brismar. (2015) P300 amplitude and response speed relate to preserved cognitive function in relapsing-remitting multiple sclerosis. Clinical Neurophysiology 2015;126(4):689-697.

10. Filippi, M, Rocca, MA, Benedict RHB, DeLuca J, Geurts JG, Rombouts, SARB, Ron, M, andComi G. (2010) The contribution of MRI in assessing cognitive impairment in multiple sclerosis. Neurology 2010;75(23): 2121-2128.

11. Mainero C, Caramia F, Pozzilli C, Pisani A, Pestalozza I, Borriello G et al. (2004) fMRI evidence of brain reorganization during attention and memory tasks in multiple sclerosis. Neuroimage 2004;21(3):858-67.

12. Roy S, Benedict RH, Drake AS, Weinstock-Guttman B.(2016) Impact of Pharmacotherapy on Cognitive Dysfunction in Patients with Multiple Sclerosis. CNS Drug 2016; 30(3): 209-225.

13. Filipovic S, Drulovic J, Stojisavljevic N, Levic Z.(1997) The effects of high-dose intravenous methylprednisolone on event-related potentials in patients with multiple sclerosis. J of Neurological Science 1997;152:147-153.

14. Baykara E, Ruf CA, Fioravanti C, Käthner I, Simon N, Kleih SC, Kübler A, Halder.(2016) Effects of training and motivation on auditory P300 brain-computer interface performance. Clin Neurophysiol 2016; 127(1):379-87. 